\title{
Samin Community Acceptance to Public Health Program in Baturejo Village, Sukolilo District, Pati Regency, Province of Central Java
}

\author{
Taufik Suprihatini \\ Communication Science Department, Faculty of Social and Politic Sciences \\ Diponegoro University \\ Semarang, Indonesia. \\ (Taufik_fspkom@yahoo.com)
}

\begin{abstract}
In effort to create a society that is healthy, smart and qualified, the government continues to do socialization and cooperation with various parties in order to facilitate the development programs that have been planned. However, to realize the program on public health, especially in Samin community in Baturejo village, Pati regency, Central Java province, is not easy. They still have their own view in maintaining and following cultural values and doctrines. This study aimed to describe the Samin community acceptance to the public health program. The researcher uses a qualitative method with descriptive research type. The key respondents of this study are midwife and a housewife. The results of this study showed that socialization conducted by midwive so that Samin community would checked their health at the doctor or clinic, or become family planning acceptors and immunize their children did not get a positive response. In the medical check, the Samin community more trusting of traditional medical treatment than modern medical tratment, while the family planning program is considered as a barrier their desire to have many children, further, immunization perceived less benefit directly.
\end{abstract}

Keywords—public health program; socialization; government; Samin community

\section{INTRODUCTION}

To realize the state according to expectations, there are many factors that are significant constrains such as the problem of Human Resources (HR), educational problems, economic problems, mental attitude, philosophy of life, the problem of integration with other residents, is also a problem tribes of diverse variety. The number of tribes which are pretty much is a problem that needs attention. According to the survey conducted by BPS (Central Bureau of Statistics) in 2010 it was known that Indonesia consisted of 1,128 tribes. (http://www.jpnn.com/index.php?mib=berita.detail\&id=57455, download on Mei 11, 2013, at. 22.22)

There are variegated tribes in Indonesia plus a number of significant tribes which affect the advancement of a nation indirectly. In the village of Baturejo, Pati regency, Central Java province, lives a group of people called Samin community. Samin Community is a community that adopts a doctrine taught by its founder namely Samin Surosentiko. These communities live in some areas of Central Java District such as Purwodadi, Pati, Kudus, Blora, and partly in the areas of East Java as in Tuban, Bojonegoro. Not all members of society implement development programs launched by the government. Some communities do not obey government programs such as Samin community in the village of Baturejo, Pati regency, Central Java province. When the government's program clash with system of values, norms or doctrines that has followed, they will keep their persistent although eventually it will be occurred the conflict to defend the doctrine or belief that has been espoused.

Health issues are a serious problem in the village. Based on field observations of Samin community, when they get sick they go to customary head or the 'old' who can provide medical treatment with traditional herbs. However, if the traditional medical treatment can not cure the diseases, midwifes and paramedics become their final destination.

In this study, researcher wants to know the acceptance of Samin community to development programs, particularly in public health program. When they accept or refuse the program, what factors that affect the acceptance or the refusal of the program. The purpose of this descriptive study is to determine the acceptance of Samin community to public health program in Baturejo village, Sukolilo distric, Pati regency, Central Java Province.

The theoretical framework of this study is Co-Cultural theory and Cultural Relativism theory. Co-cultural theory developed by Mark Orbe, a theory that explains the conversation between members of dominant group and who represented, including those who are colored, women, gay, lesbian, bisexual, and transgender, people who are not capable, and so on. This theory is spesific, from the perspective of the members who represented when they feel that cultural differences are felt. Moreover, this theory also provides an understanding of how the co-culture group members overcome their cultural differences with other cultures.(Littlejohn and Foss, 2009: 263-264)

Cultural relativism is based on the idea that cultural development is not the same in every region in the hemisphere. There is relative boundary between one culture to another. The 
social environment, physical environment, and human behavior are a system that sets the culture of a person or group of people. So if a culture is not the same, there is a relative difference between one culture to another, depends on the social environment, human behaviour and physical environment. If the cultural development between the one culture area is different from other culture area, the standard of truth and goodness every cultural group will be different from one another. This basic forms cultural values that are relatively. Cultural relativism considers that no culture that is better than other cultures. Therefore, there is no truth or fault that is international. Cultural relativism refuses the notion that there is universal truths of certain cultures. Cultural relativity is a principle that the beliefs and activities of the individual must conceived based on the culture.

\section{RESEARCH METHOD}

\section{A. Type of Research}

In this study, the researcher uses qualitative method with descriptive type that aims to describe in detail the social phenomena of Samin community relating to the acceptance of Samin community to public health program from local government.

The data collected are in the form of words and images, derived from in-depth interviews, field notes, memos and other official documents. Research reports quotations of data to illustrate the presentation of the report.

\section{B. Site Research}

Selection of background (the site) is based on the interpretive paradigm, therefore natural background becomes background category selection. The background research is in Bombong hamlet, the village of Baturejo, Sukolilo district, Pati regency as a dwelling place for Samin community in Central Java Province.

\section{RESEARCH RESULT}

The research subjects of this study are midwife as informant 1 and housewive as informant 2 .

The result shows that the Samin community is very difficult to participate program that comes from the government. Socialization program is conducted by informant 1 so that Samin people will do medical treatments, become family planning acceptors and give immunization to their children, but it doesn not get a positive response. Low level of education (elementary school) cause they do not understand about the benefits of family planning, and immunization. But not all Samin people will not domedical treatment and give immunization for their children. Some of them who are willing to do the medical treatment, became acceptors of family planning and give immunization for their children are non Samin people (ordinary people) and Samin people who are married to non Samin people.

While in the Samin community, they turned it down because they have a negative outlook. They also lack of understanding of the factors that cause diseases and the way to treat it. Sothey think immunization is less perceived benefits. Whereas in the case of health checks, they more trusting of traditional medical treatments through the customary head or a person who is considered to be a treat than modern medical treatments. However, traditional medical treatment is not the only way to treat the diseases. When the traditional medical treatments can not cure the diseases, then they refer to paramedics around the village, or hospital. Similarly, in participating family planning program, although people of Baturejo village have already understood the aim of family planning program, but people who want to become acceptors of the program are relatively small. It is due to the failure of non Samin people who is participating in the family planning program. Such information is then spread throughout the villages. Additionally people of Baturejo village still adopts "Many children have a lot of luck", thus family planning program is considered as a barrier their desire to have many children, and they consider that the program is less benefit. Another difficulty that is felt by informant 1 , because all things that are in the form of orders considered as element of coercion, pressure, even threats that do not related with the attitude that has been done by the Samin community. Therefore they always refuse the messages conveyed by the government, because they think it has no benefits for themselves.

\section{CONCLUSION}

Socialization is conducted by midwife so that people will go to the health center, doctor or midwife, and give immunization to their children does not get positive response, because they consider that immunization perceived less benefit. In the medical check, the people of Baturejo village more trusting of traditional treatments than modern medical treatments. Similarly, the people who participate the family planning program are relatively small. It is because of the problems afflicting the non Samin people. The culture of having many children has become a tradition for generations. Another difficulty, for all things that are in the form of orders considered as element of coercion, pressure, even threats that do not related with the attitude that has been done by Samin community.

\section{A. Suggestion}

There should be a policy of the local government to promote health issues intensely to the Samin community either directly or indirectly through mass media or traditional media so they have an understanding and awareness in the health sector.

\section{ACKNOWLEDGMENT}

Because of the difficulty in finding informants of Samin people who can answer the questions well, the informant in this study is from non Samin people.

\section{REFERENCES}

[1] Denzim, Norman K. dan Lincoln, Ivonna S. (editors), 1994, Handbook of Qualitative Research, Sage Publications Inc. 2455 Teller Road Thusand Oaks, California 
[2] DeVito, Joseph A.,1997, Komunikasi Antar Manusia, Edisi ke Lima, Jakarta: Professional Books

[3] Gudykunst, William B. and Kim, Young Yun, 1997, Communicating With Strangers, An Approach To Intercultural Communication, Third Edition, The McGraw-Hill Companies Inc., United States of America'

[4] Gudykunst, William R., (Ed.), 2005, Theorizing About Intercultural Communication, Sage Publication, United State of Amerika

[5] Herskovits, Melville Jean, 1972, Cultural Relativism: Perspectives in Cultural Pluralism, Random House, Vintage Books

[6] Hutomo, Suripan Sadi, 1985, Samin Surontiko dan Ajaran-ajarannya, Yogyakarta, Basis, Januari, XXXIV

[7] Jandt, Fred E., 2004, An Introduction to Intercultural Communication, Identities in a Global Community, Fourth Edition, Sage Publication, Inc., California

[8] Lewis, Glen and Slade, Christina, 1994, Critical Communication, Prentice Hall Australia
[9] Littlejohn, Stephen W. Dan Foss, Karen A. 2009, Teori Komunikasi, Edisi 9, Penerbit Salemba Humanika, Jakarta

[10] Littlejohn, Stephen W. and Foss, Karen A.(Editor), 2009, Encyclopedia of Communication Theory, A Sage Reference Publication California

[11] Moustakas, Clark, 1994, Phenomenological Research Methods, Sage Publications, Inc. California

[12] Samovar, Larry A., Porter, Richard E, Mc Daniel, Edwin R.,2010, Komunikasi Lintas Budaya, Communication Between Cultures, Edisi 7, Penerbit Salemba Humanika, Jakarta

[13] Ting-Toomey, Stella, 1999, Communicating Across Cultures, The Guildford Press, New York

[14] West, Richard dan Lyn H.Turner, 2008, Pengantar Teori Ilmu Komunikasi, Edisi 3, Jakarta: Salemba Humanika

[15] http://www.jpnn.com/index.php?mib=berita.detail\&id=57455, download on Mei 11, 2013 at. $22.22 \mathrm{pm}$ ) 